\title{
THE EFFECTS OF OWNERSHIP CONCENTRATION ON PERFORMANCE OF PAKISTANI LISTED COMPANIES
}

\author{
Nouman Afgan', Klaus Gugler², Robert Kunst ${ }^{3}$
}

\begin{abstract}
This paper analyzes the effects of ownership concentration on investment performance in a large sample of Pakistani publicly-listed companies from 1997 to 2007. Special attention is directed to statistical methods from the field of panel-data econometrics, which are able to deal with endogeneity problems and with structural reverse causality. The preferred estimator that is based on firm fixed effects insinuates that the voting rights of ultimate shareholders affect Tobin's $q$ unambiguously negatively, whereas the squared voting rights affect it unambiguously positively. This implies a U-curved relationship between Tobin's $q$ and voting rights concentration with a turning point at $45 \%$. More than $75 \%$ of the companies fall in the upward sloping part of the curve. While positive incentive effects are at work in Pakistan, financial market development is retarded by the reluctance of minority shareholders facing dominant shareholders to hold small stakes in listed companies. Consistently, institutional shareholders do not yet provide a positive monitoring role in Pakistan.
\end{abstract}

JEL Classification Numbers: L2, G3, DOI: http://dx.doi.org/10.12955/cbup.v4.764

Keywords: corporate governance, ultimate ownership, institutional shareholdings, endogeneity of ownership, and investment performance.

\section{Introduction}

The analysis of the effects of ownership concentration on investment performance is an important strand of the literature on corporate governance since the pioneering work of Morck, Shleifer, and Vishny (1988). In a sample of large U.S. companies, they found that Tobin's $q$ displays a Z-shaped non-monotonic reaction to managerial shareholdings: a positive relation holds up to $5 \%$; between $5 \%$ and $25 \%$, a negative relation dominates; thereafter, a positive relation takes over once more. They interpreted the positive part of the relation as being consistent with incentives becoming more and more aligned between outside shareholders and managers, i.e. managerial shareholdings overcome the problem of the separation of ownership and control. If managers hold a substantial stake in the company, however, it is nearly impossible to replace them. Thus, there is a range of their shareholdings where they destroy more value than they add. They become entrenched.

The analysis of the effects of ownership concentration on performance is important for industrialized countries; it is all the more important for the developing economy of Pakistan. Only if entrenchment effects and private benefits of control are reasonably low, will small, minority shareholders feel safe to invest in the shares of listed companies. Only if capital market institutions properly protect them against managers and - in the case of Pakistan more importantly - against dominant shareholders, will external capital markets develop.

This paper analyzes the ownership structures of 125 Pakistani listed companies over the period 1997 to 2007. It is the first study on a South Asian country that exploits the time series variation in ultimate ownership to control for the endogeneity problem of structural reverse causality, by estimating firm fixed and random effects models (see also Demsetz \& Lehn, 1985). The relationship between Tobin's $q$ and voting rights' concentration is a U-curve with a turning point at $45 \%$. Although more than $75 \%$ of the companies fall in the upward sloping part of the curve, doubt arises as to whether capital market institutions properly protect minority shareholders.

Section 2 gives a short overview of the ownership concentration and investment performance literature. Section 3 describes the method used to calculate ultimate ownership. Section 4 presents the estimating equation for measuring the effects of ownership concentration on performance. In section 5,

\footnotetext{
${ }^{1}$ Nouman Afgan, Department of Quantitative Economics, Vienna University of Economics and Business, Vienna, Austria, nafgan@wu.ac.at,

${ }^{2}$ Klaus Gugler, Department of Quantitative Economics, Vienna University of Economics and Business, Vienna, Austria,

klaus.gugler@wu.ac.at,

${ }^{3}$ Robert M. Kunst, Department of Economics, University of Vienna, Austria, robert.kunst@univie.ac.at,
} 
we describe the sources of information, and report the descriptive statistics of variables used in the analysis. Section 6 comprises of panel-data analyses of the effects of ownership concentration on performance. Conclusions are drawn in the final section.

\section{Literature Review}

Tobin (1969) illustrated the capital account approach (schematic) for a closed economy. In his ge neral accounting framework, a row is labeled as demand deposits or the producers' durable equipment, whereas columns represent sectors of the economy that are constrained by their own wealth. Examples of sectors are commercial banks, central bank, non-bank financial institutions, and the general public. According to the author, financial policies and events mainly affect aggregate demand by changing the valuations of physical assets relative to their replacement costs. Financial policies can accomplish such changes, but so can other exogenous events.

In a seminal article, Morck, Shleifer, and Vishny (1988) study ownership concentration and investment performance of 371 of the Fortune 500 companies. Morck et al. (1988) use shareholdings of the board of directors as a proxy for managerial ownership and draw a non-linear relationship between ownership concentration and Tobin's $q$. McConnell and Servaes (1990) analyze a large sample of US companies, and report an up /down relationship between managerial ownership and Tobin's $q$. Thus, they observe only the first part of the inverted parabola. Short and Keasey (1999) use a sample of 225 listed companies from the United Kingdom for studying the impact of ownership concentration on investment performance and report a a non-linear relationship between the former and the latter.

Xu and Wang (1999) analyze the ownership and financial data of all companies listed on the Shanghai and Shenzen stock exchanges over the 1993 to 1995 period and report a positive and significant correlation between ownership concentration and profitability, and they find that the impact of ownership concentration on profitability is stronger for companies owned by legal person shareholders than for those owned by the State. Profitability is positively correlated with the percentage of legal person shareholdings, but it is either negatively correlated or uncorrelated with the percentage of state shares and shares held by individuals. Liu and Sun (2003) show that the absence of state-shares in the pattern of shareholding disclosed in a company's annual report does not necessarily indicate the nonexistence of ultimate control by the state. According to their analysis, the class of legal shares is only a veil of various identities of ultimate owners, including both state and private. Whether and to what extent, this ambiguity dilutes the findings on the impact of shareholding classes on performance is difficult to predict.

Yeh, Lee, and Woidtke (2001) used a sample of 208 Taiwanese listed companies for studying the impact of ownership concentration on financial performance for 1994 to 1995. Family-controlled companies, with low levels of control have worse performance than family-controlled companies with high levels of control and companies that are widely held.

Lemmon and Lins (2003) analyzed the ownership structures and performance of sample of 800 listed companies from South East Asian countries during the Asian Financial crisis. They hypothesize that, during the crisis, values should show the strongest decline in those companies where dominant shareholders or managers use ownership structures that allow them to control companies while reducing the cash flow rights associated with voting rights. Cumulative stock returns of companies, whose managers had high voting rights separated from cash flow rights, are 10 to $20 \%$ lower than in companies in which managers have low voting rights.

Joh (2003) uses a large sample of Korean companies, for estimating the relationship between ownership structures and accounting performance. The measure of accounting performance used is the net income to assets ratio. Ownership concentration is found to have a substantial positive impact on accounting performance. By contrast, companies with a high disparity between voting and cash flow rights have lower performance. This effect is especially true for companies that were members of the top thirty chaebols. In the interval below 5\%, company performance declines with ownership, whereas it increases sharply in the interval from $5 \%$ to $25 \%$. Above the $25 \%$ level, performance increases gradually with ownership concentration. Thus, ownership concentration has a non-linear effect on accounting performance. 
Several authors have focused on Malaysia in this context. Samad (2002) analyzed corporate governance and investment performance of Malaysian listed companies over the 1989 to 1998 period. $\mathrm{He}$ measured performance with return on equity and return on assets. The regression analysis performed in his study insinuates that, as companies grow larger, they become more profitable and rely less on debt financing. He concludes that being part of a business conglomerate is negatively related to performance.

Mak and Kusnadi (2005) studied the impact of ownership concentration on corporate performance in Malaysia. Their main finding was that block shareholdings had a small positive effect on Tobin's $q$, which is marginally significant. Haniffa and Hudaib (2006) study the effect of ownership concentration, board composition, and multiple directorships on performance of Malaysian companies. They analyze a sample of 347 companies listed on the Kuala Lampur Stock Exchange for the 1996 to 2000 period. They find that shareholdings of the five largest shareholders and board size are significantly associated with Tobin's $q$ and return on assets. Tam and Tan (2007) analyze ownership structures and performance of listed Malaysian companies from 1994 to 2001 . The measures of performance used are Tobin's $q$ and return on assets. Ownership types (individuals, state, and foreign) are found to exert significant impact on performance. The impact varies, however, with the performance measure, the business conditions, and the socio-economic policy that influences the distribution of wealth in Malaysia.

Sarkar and Sarkar (2000) use a large sample of Indian listed companies for studying the effects of ownership concentration on performance. The focus of their paper is on the relationship between the ownership stakes of directors and corporate shareholders and company valuation as measured by the market to book ratio. They find that block-holdings by directors increase company value after a certain level of shareholdings. Kumar (2008) analyzes the effects of ownership concentration on performance of Indian companies over 1994 to 2000. He uses return on assets for measuring performance and estimates a U-curved relationship between shareholdings of directors and performance.

Farooque, Zijl, Dunstan, and Karim (2007) analyze a sample of 73 Bangladeshi companies and report an S-shaped non-linear relationship between board ownership and performance, with entrenchment dominating for small and large ownership ratios, essentially a mirror image of the function reported by Morck et al. (1988). However, the non-linear reaction disappears when a 2-stage least squares estimation of a simultaneous equation model is carried out.

Javed and Iqbal (2008) analyze ownership structures and performance of Pakistani companies. They use a sample of sixty companies for analyzing the effect of ownership on performance. Return on assets and Tobin's $q$ are used as measures of firm performance. Family and Foreign are found to positively affect performance.

In summary, all studies on ownership concentration and performance do find a range of ownership with a positive effect on performance. However, most studies also find ranges where the net effect of additional ownership concentration is negative. There are no studies for South Asian countries that use panel-estimation techniques to control for possible endogeneity of ownership and performance.

\section{Ownership Structures}

Ownership structures of Pakistani listed companies are highly concentrated. Analysis of ownership structures shows that families, directly or indirectly, own $55.20 \%$ of the companies. The concept of a pyramidal structure is explained by illustrating the ownership structure of Maple Leaf Cement in figure 1 .

Maple Leaf Cement ${ }^{1}$ uses the one-share one-vote principle for issuance of shares (see Burkart \& Lee, 2008). The company's largest direct shareholder is Kohinoor Textile Mills with shareholdings of $50.13 \%$, which exports fabrics. Kohinoor Textile's largest direct shareholder is Zimpex Private Limited that has shareholdings of $15.47 \%$. Zimpex Private Limited is fully-owned at the top of the pyramidal structure by its directors, Tariq Sayeed Saigol and Taufique Sayeed Saigol, whose voting rights $(V R)$ are calculated as follows:

Voting Rights $(\mathrm{VR})=0.01+50.13+0.04=50.18 \%$ or 0.502

Cash flow rights are calculated by multiplying and summing all relevant control chains as follows: 
Cash flow rights $(C F R)=0.01+0.5013 \times(0.1547+.1491)+0.04$

$$
C F R=15.28 \% \text { or } 0.15
$$

Figure 1: Ownership Structure of Maple Leaf Cement

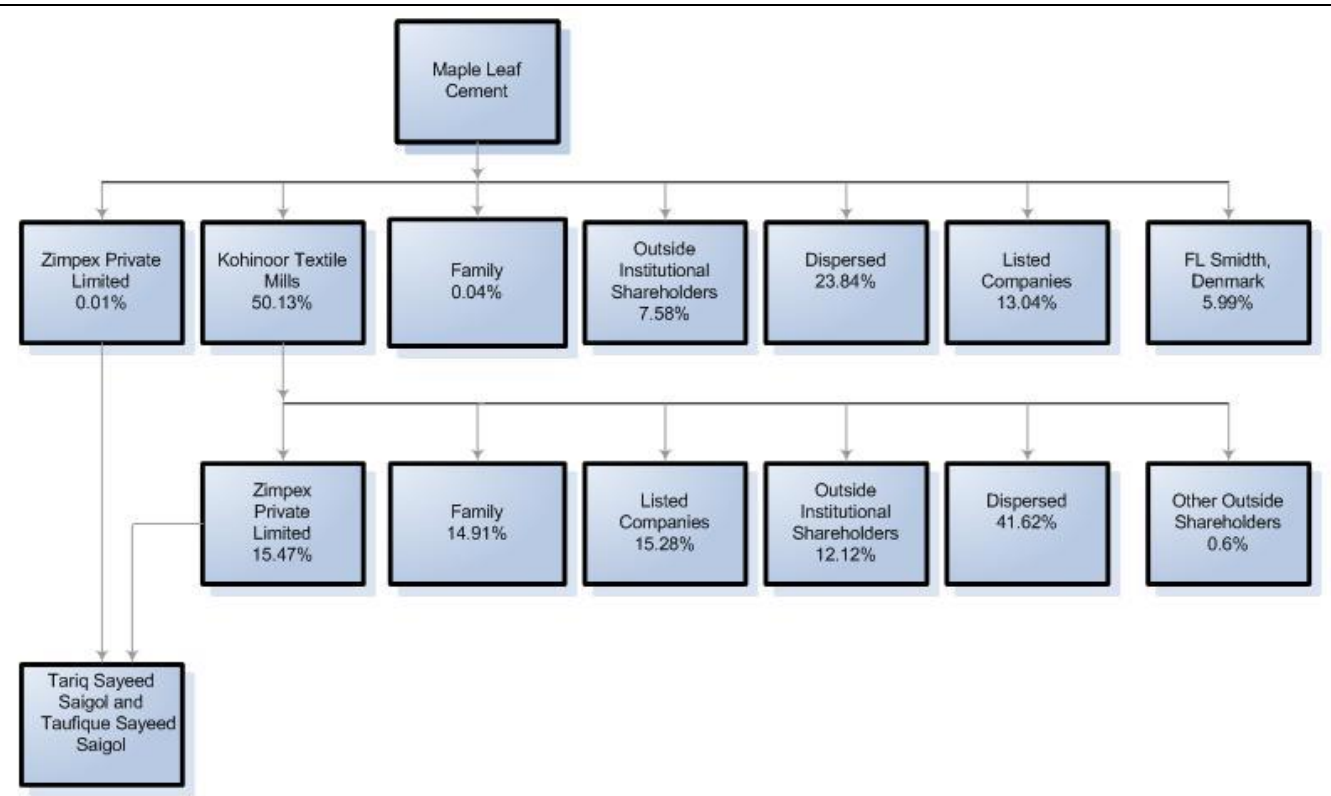

Source: Author

Cash flow leverage $(V R / C F R)$ is 3.28. Pyramidal structures lead to a divergence of the interests of the largest ultimate shareholder and those of outside shareholders because voting rights of the ultimate shareholder exceed cash flow rights (see e.g. Almeida \& Wolfenzon, 2006).

Table 1 reports the ownership concentration by the identity of direct and ultimate shareholders. Ownership reports mean (median) of ownership whenever these identities are largest direct shareholders and voting rights are applicable to the largest ultimate shareholders that are families, the state, and foreign entities. Diverging voting rights and cash flow rights are not analyzed because voting rights exceed cash flow rights in $11.2 \%$ of the companies.

Table 1: Ownership and control structures of Pakistani listed companies

\begin{tabular}{|c|c|c|c|c|c|c|c|}
\hline \multirow{3}{*}{$\begin{array}{l}\text { Ownership } \\
\text { Panels }\end{array}$} & \multicolumn{3}{|c|}{ Direct Ownership Panel } & \multicolumn{4}{|c|}{ Ultimate Ownership Panel } \\
\hline & \multicolumn{3}{|c|}{ Largest Direct Shareholders } & \multicolumn{4}{|c|}{ Largest Ultimate Shareholders } \\
\hline & Companies & Owne & & Voting & ghts $(V R)$ & Companies & \\
\hline $\begin{array}{l}\text { Ownership } \\
\text { Identity }\end{array}$ & Percentage & Mean & Median & Mean & Median & Percentage & $\begin{array}{l}\text { Number } \\
(N)\end{array}$ \\
\hline $\begin{array}{l}\text { Listed } \\
\text { Companies }\end{array}$ & 8.00 & 36.25 & 37.04 & & & & \\
\hline $\begin{array}{l}\text { Private } \\
\text { Companies }\end{array}$ & 10.40 & 46.51 & 44.43 & & & & \\
\hline $\begin{array}{l}\text { Holding } \\
\text { Companies }\end{array}$ & 4.00 & 62.48 & 55.00 & & & & \\
\hline $\begin{array}{l}\text { Institutional } \\
\text { Shareholders }\end{array}$ & 1.60 & 30.56 & 30.56 & & & & \\
\hline Trusts & 4.80 & 40.28 & 40.00 & & & & \\
\hline Families & 30.40 & 48.03 & 43.46 & 52.02 & 46.58 & 55.20 & 69 \\
\hline State & 6.40 & 60.72 & 60.30 & 61.89 & 60.93 & 10.40 & 13 \\
\hline Foreign & 34.40 & 61.23 & 62.02 & 67.94 & 66.92 & 34.40 & 43 \\
\hline Total & 100.00 & 52.45 & 50.88 & 58.56 & 54.53 & 100.00 & 125 \\
\hline
\end{tabular}


Tracing the ultimate ownership of companies shows that families and the state control $55.2 \%$ and $10.4 \%$ of the companies respectively. Foreign entities control $34.40 \%$ of the companies. However, none of these entities have the state as the ultimate shareholder. Table 1 illustrates that ultimate ownership is a more meaningful concept than direct ownership. In Pakistan, the concentration of ultimate voting rights, i.e. voting rights by the largest ultimate share holders, is high, with the mean (median) reaching $58.6 \%(55 \%)$.

\section{Estimating Equation}

It appears plausible that investment performance of listed companies may be non-linearly related to the voting rights of ultimate shareholders. Investment performance is measured by Tobin's $q$, which is the ratio of market value of a company to its total assets. A firm fixed effects model is used to regress Tobin's $q$ on the lagged values of voting rights of the largest ultimate shareholder, square of voting rights, leverage, shareholdings of outside institutional shareholders, company size, and growth (refer to the appendix for definitions of variables). A negative coefficient on voting rights (VR) indicates that the largest shareholders or managers are entrenched with intermediate shareholdings and divert corporate resources from minority shareholders to themselves. A positive coefficient on the square of voting rights $\left(\mathrm{VR}^{2}\right)$ indicates that a sufficiently large stake of the largest ultimate shareholder provides incentives to increase firm value.

Leverage is hypothesized to positively affect performance, not only because of tax advantages of debt but also due to the disciplinary role of debt (see Jensen, 1986). If institutional shareholders in a company effectively monitor its operations, their shareholdings are expected to positively affect performance. If institutional shareholders suffer themselves from agency costs and side with managers or largest dominant shareholders, we expect the reverse (see Short \& Keasey, 1997).

Company size is expected to have a positive coefficient if larger companies are more transparent and better disclose their results. Larger companies could be more diversified than smaller companies, which leads to lower risk, but also to larger diversification discounts. Growth is used as a proxy for growth opportunities and is expected to have a positive effect on performance. Larger companies could be more diversified than smaller companies, which leads to lower risk, but also larger diversification discounts. Growth is used as a proxy for growth opportunities and is expected to have a positive effect on performance. The model is written in linear form as follows:

$$
q_{i t}=\alpha+b_{1} V R_{i, t-1}+b_{2} V R_{i, t-1}^{2}+b_{3} L_{i, t-1}+b_{4} I T_{i, t-1}+b_{5} \mathrm{~S}_{\mathrm{i}, t-1}+b_{6} \mathrm{G}_{i, t-1}+\mu_{i}+v_{i, t} .
$$

Where qit denotes Tobin's $q$ of the -ith company in period $\mathrm{t}, \mathrm{VR}_{\mathrm{it}-1}$ denotes voting rights of the ultimate shareholder in period ( $\mathrm{t}-1), \mathrm{VR}_{\mathrm{it}-1}{ }^{2}$ denotes square of voting rights, $\mathrm{L}_{\mathrm{it}-1}$ denotes leverage, $\mathrm{IT}_{\mathrm{it}-1}$ denotes outside institutional ownership, $\mathrm{S}_{\mathrm{it}-1}$ denotes size, $\mathrm{G}_{\mathrm{it}-1}$ denotes growth, $\mu_{i}$ denotes the unobserved company effect, and $v_{i t}$ is the error term.

\section{Data}

A sample of 125 largest companies listed at the Karachi Stock Exchange was chosen that accounts for 98 percent of the stock exchange's capitalization. Financial companies are excluded from the sample because their capital is not comparable to non-financial companies.

Annual financial reports from 1997 to 2007 were solicited from the companies as well as from secondary sources of information such as the State Bank of Pakistan, Lahore Stock Exchange, and Karachi Stock Exchange. The stock prices data from 1996 to 2007 were prepared from the newspapers, Dawn and Business Recorder. The ownership and financial information obtained from the above-mentioned sources were used to prepare the panel data. The analysis uses unbalanced panels because all companies were not listed from 1997 to 2007. The Consumer Price Index (CPI) was used to convert nominal values of the financial variables into real 1991 Rupees.

Redeemable preference shares are allowed by the Companies' Share Capital Variation in Rights and Privileges Rules, 2000. Redeemable preference shares (non-voting) that pay fixed annual dividends were used in seven companies. 
Summary statistics and matrix of correlation coefficients are reported in Table $2(* * *, * *, *$ denote significance levels of $1 \%, 5 \%$, and $10 \%$ respectively). The Sidak method is used to assess the significance levels of correlation coefficients (see Hamilton, 1992).

Table 2: Summary statistics of variables and matrix of correlation coefficients

\begin{tabular}{|c|c|c|c|c|c|c|}
\hline Variable & Tobin's $q$ & $\begin{array}{l}\text { Voting Rights } \\
\text { (VR) }\end{array}$ & $\begin{array}{l}\text { Leverage } \\
\text { (L) }\end{array}$ & $\begin{array}{c}\text { Institutional } \\
\text { Ownership } \\
\text { (IT) }\end{array}$ & $\begin{array}{c}\text { Size } \\
(\mathbf{S})\end{array}$ & $\begin{array}{l}\text { Growth } \\
\text { (G) }\end{array}$ \\
\hline $\begin{array}{c}\text { Mean } \\
\text { (Median) }\end{array}$ & $\begin{array}{c}1.62 \\
(1.10)\end{array}$ & $\begin{array}{l}58.56 \\
(54.53)\end{array}$ & $\begin{array}{c}0.14 \\
(0.07)\end{array}$ & $\begin{array}{l}12.27 \\
(9.40)\end{array}$ & $\begin{array}{c}15.82 \\
(15.80)\end{array}$ & $\begin{array}{l}0.32 \\
(0.12)\end{array}$ \\
\hline \multicolumn{7}{|l|}{$\begin{array}{l}\text { Correlation } \\
\text { coefficients }\end{array}$} \\
\hline $\begin{array}{l}\text { Voting Rights } \\
\text { (VR) }\end{array}$ & $0.23 * * *$ & & & & & \\
\hline Leverage $(\mathbf{L})$ & -0.03 & -0.05 & & & & \\
\hline $\begin{array}{c}\text { Institutional } \\
\text { Ownership (IT) }\end{array}$ & $-0.19 * * *$ & $-0.55 * * *$ & $-0.05^{*}$ & & & \\
\hline Company Size (S) & $-0.05^{* *}$ & 0.04 & $0.19 * * *$ & 0.06 & & \\
\hline Growth (G) & -0.03 & 0.02 & 0.01 & 0.03 & 0.04 & \\
\hline
\end{tabular}

\section{Empirical Analysis}

The results of firm fixed effects are reported in table $3(* * *, * *, *$ denote significance levels of $1 \%$, $5 \%$, and $10 \%$ respectively).

Table 3: Firm fixed effects (FE) and Random Effects (RE)

\begin{tabular}{|c|c|c|}
\hline \multirow[t]{2}{*}{ Panel 1} & Firm Fixed Effects & Random Effects \\
\hline & $\begin{array}{l}\text { Coefficient } \\
\text { (SE) }\end{array}$ & $\begin{array}{l}\text { Coefficient } \\
\text { (SE) }\end{array}$ \\
\hline $\begin{array}{l}\text { Voting Rights } \\
\text { (VR) }\end{array}$ & $\begin{array}{c}-4.77 * * * \\
(1.756)\end{array}$ & $\begin{array}{c}-4.09 * * * \\
(1.311)\end{array}$ \\
\hline $\begin{array}{l}\text { Voting Rights } \\
\text { Square }\left(\mathbf{V R}^{2}\right) \\
\end{array}$ & $\begin{array}{l}5.33 * * * \\
(1.350)\end{array}$ & $\begin{array}{l}4.60 * * * \\
(1.053)\end{array}$ \\
\hline Leverage (L) & $\begin{array}{l}0.65 * * * \\
(0.235) \\
\end{array}$ & $\begin{array}{l}0.38 * * \\
(0.211) \\
\end{array}$ \\
\hline $\begin{array}{c}\text { Institutional } \\
\text { Ownership (IT) } \\
\end{array}$ & $\begin{array}{l}-0.08 \\
(0.071) \\
\end{array}$ & $\begin{array}{c}-1.23 * * * \\
(0.322) \\
\end{array}$ \\
\hline Company Size (S) & $\begin{array}{l}0.12 * * * \\
(0.035)\end{array}$ & $\begin{array}{l}0.06^{* *} \\
(0.029) \\
\end{array}$ \\
\hline Growth (G) & $\begin{array}{c}0.01 \\
(0.032) \\
\end{array}$ & $\begin{array}{c}0.00 \\
(0.019) \\
\end{array}$ \\
\hline$\alpha$ & $\begin{array}{l}0.95 * * * \\
(1.187) \\
\end{array}$ & $\begin{array}{c}0.83 \\
(0.595) \\
\end{array}$ \\
\hline Observations & 1227 & 1227 \\
\hline Correlation $\left(\mu_{\mathrm{i}}, \mathrm{Xb}\right)$ & $-0.30 * * *$ & $\begin{array}{c}0.00 \\
\text { (assumed) }\end{array}$ \\
\hline \multicolumn{3}{|c|}{ Chow Test for data pooling } \\
\hline \multicolumn{3}{|c|}{$H_{0}:$ Deviations from the global intercept ( $\alpha$ ) are zero for all companies } \\
\hline \multicolumn{2}{|c|}{$F$-statistic } & $7.89 * * *$ \\
\hline \multicolumn{3}{|c|}{ Firm fixed effects are preferred over pooled ordinary least squares } \\
\hline \multicolumn{3}{|c|}{ Hausman Test } \\
\hline \multicolumn{3}{|c|}{$\begin{array}{l}H_{0} \text { : Coefficients estimated by the efficient random effects estimator are asymptotically identical to those estimated by } \\
\text { the consistent fixed effects estimator }\end{array}$} \\
\hline \multicolumn{2}{|c|}{ Chi-square $\left(\chi^{2}\right)$ statistic } & $28.38 * * *$ \\
\hline \multicolumn{3}{|c|}{ Firm fixed effects are preferred over random effects. } \\
\hline Source: Author & & \\
\hline
\end{tabular}


Firm fixed effects show that voting rights (VR) is negative and significant, whereas square of voting rights is positive and significant. Thus, the estimates imply that up to a VR ratio of approximately $45 \%$, performance is reduced as the negative entrenchment effect dominates the positive incentive effect. From a holding of $45 \%$ onwards, the reverse is true. For $75 \%$ of the companies, VR concentration has a positive effect on performance (see Figure 2). Leverage (L) and company size (S) obtain positive and significant coefficients, while institutional shareholdings (IT) and growth (G) are insignificantly related to Tobin's $q$.

Random effects are also estimated and essentially no change was observed in results for voting rights $(\mathrm{VR})$, and square of voting rights $\left(\mathrm{VR}^{2}\right)$. The main differences of results of random effects from those of fixed effects are that the coefficient on institutional shareholdings (IT) becomes negative and significant at $1 \%$ level. The coefficients on leverage (L), and company size (S) remain positive but significant at $5 \%$ level.

Firm fixed effects are preferred to random effects because the null hypothesis of the Hausman test can be rejected. Although, fixed effects are preferred to random effects, an insignificant or even negative effect of institutional shareholdings on performance cannot be ruled out. Agency costs in these institutions themselves in Pakistan may be responsible for evidence on negative effects of institutional shareholdings on performance.

The null hypothesis under the Chow test for data pooling that deviations from the global intercept $(\alpha)$ are zero for all companies can be rejected. Thus, firm fixed effects are preferred to pooled ordinary least squares.

\section{Conclusion}

This is the first paper on a South Asian developing country that uses panel data modelling for estimating the effects of ownership concentration on investment performance, thereby addressing the endogeneity problem of reverse causality. Firm fixed effects show that the voting rights (VR) of ultimate shareholders unambiguously negatively, and the square of voting rights $\left(\mathrm{VR}^{2}\right)$ unambiguously positively, affect Tobin's $q$ implying a U-curved relationship between Tobin's $q$ and concentration of voting rights with a turning point at $45 \%$.

More than $75 \%$ of the companies fall under the upward sloping part of the curve. The intuitive explanation of the upward slope is that the incentive of the owner to improve performance dominates the negative entrenchment effect from this point onwards. However, up to $45 \%$ voting rights ultimate shareholders destroy value on balance for minority shareholders.

This implies that a substantial concentration of ownership is necessary to secure the positive incentive effects of ownership. Viewed differently, financial markets remain underdeveloped if minority shareholders are reluctant to hold stakes in publicly listed companies facing possible expropriation by dominant shareholders. Consistently, institutional shareholders do not yet provide a positive monitoring role in Pakistan.

\section{Acknowledgements}

We are grateful to the Higher Education Commission that supported the research. We are grateful to Tanvir Afgan, Florian Gach, Heide Marie Wurm, Ashraf Bawa, Assad Hameed Khan, S. M. Saad Jafri, M. Salman Ali Bokhari, Saqib Masood, Arshad Mahmood, Tanveer Iqbal, Muhammad Afzal, Bilal Rasul, Asif Jalal, Bilal Durrani, Hasan Ashraf, Abdul Aziz Anis, and Farhan Talib for their cooperation in the process of collecting information.

\section{Notes}

Maple Leaf Cement was the highest traded equity at the Karachi Stock Exchange on August 21, 2014 and April 8, 2015.

\section{References}

Almeida, H., \& Wolfenzon, D. (2006). A Theory of Pyramidal Ownership and Family Business Groups. Journal of Finance, 61: 2637-2680.

Burkart, M., \& Lee, S. (2008). One Share- One Vote: The Theory. Review of Finance, 12: 1-49.

Demsetz, H., \& Lehn, K. (1985). The Structure of Corporate Ownership: Causes and Consequences. Journal of Political Economy, 93: 1155-1177. 
Farooque, O. A., Zijl, T. A., Dunstan, K. \& Karim, A. K. M. (2007). Corporate Governance in Bangladesh: link between Ownership and Financial Performance. Corporate Governance: An International Review, 15: 1453:1468.

Hamilton, L. C. (1992). Statistics with Stata. Canada: Duxbury.

Haniffa, R., \& Hudaib, M. (2006). Corporate Governance Structure and Performance of Malaysian Listed Companies. Journal of Business Finance and Accounting, 33(7) and 33(8): 1034-1062.

Javed \& Iqbal (2008). Ownership Structure and Firm Performance: Evidence from Pakistan's Manufacturing Industries. Working Paper; Quaid-e-Azam University, Pakistan.

Jensen, M. (1986). Agency Costs of Free Cash Flow, Corporate Finance, and Takeovers, American Economic Review, 76: 323-329.

Joh, S. W. (2003) .Corporate Governance and Firm Profitability: Evidence from Korea Before the Economic Crisis. Journal of Financial Economics, 68: 287-322.

Kumar, J. (2008). Does Ownership Structure influence Firm Value: Evidence from India. Working Paper; Indira Gandhi Research Institute, New Delhi.

Lemmon, M. \& Lins, K. V. (2003). Ownership Structure, Corporate Governance, and Firm Value: Evidence from the South East Asian Financial Crisis. Journal of Financial Economics, 58: 1445-1468.

Liu, G. S., \& Sun, P. (2003). Identifying Ultimate Controlling Shareholders in Chinese Public Corporations: An Empirical Survey. Working Paper no. 1, Asia Programme.

Mak, Y. T., \& Kusnadi, Y. (2005). Size really matters: Further evidence on the negative relationship between Board Size and Firm Value. Pacific Basin Finance Journal, 13: 301-318.

McConnell, J. J., \& Servaes, H. (1990). Additional Evidence on Equity Ownership and Corporate Value. Journal of Financial Economics, 27: 595-612.

Morck, R., Shleifer, A., \& Vishny, R. (1988). Management Ownership and Market Valuation: An Empirical Analysis, Journal of Financial Economics, 20: 293-315.

Samad, A. F. (2002). Ownership Structure in the Malaysian Corporate Sector: Its Impact on Corporate Governance, Performance, Financing, and Investment Patterns. Working Paper; University of Manchester.

Sarkar, J., \& Sarkar, S. (2000). Large Shareholder Activism in Corporate Governance in Developing Countries: Evidence from India. International Review of Finance, 1: 161-194.

Short, H. \& Keasey, K. (1997). Institutional Shareholders and Corporate Governance, in K. Keasey and M. Wright (eds.), Corporate Governance, John Wiley \& Sons.

Short, H., \& Keasey, K. (1999). Managerial Ownership and the Performance of Firms: Evidence from the UK. Journal of Corporate Finance, 5: 79-101.

Tam, K., and Tan, M.G. (2007) Ownership, Governance and Firm Performance in Malaysia. Corporate Governance and International Review, 15(2): 208-222.

Tobin, J. (1969) A General Equilibrium Approach to Monetary Theory. Journal of Money Credit and Banking, 1:15-29.

Xu, X., and Wang, Y. (1999) Ownership Structure and Corporate Governance in Chinese Stock Companies. China Economic Review, 10: 75-98.

Yeh, Y. H., Lee T.S., and Woidtke, T. (2001) Family Control and Corporate Governance: Evidence from Taiwan. International Review of Finance, 2: 21-48 


\section{Appendix}

\section{Definitions}

One share- one vote principle: Each common share carries one vote.

Dispersed Shareholdings: Percentage of shares owned by a large number of individual shareholders in a publicly- listed company.

Institutional Ownership (IT): Percentage of a listed company’s shares owned by outside institutional shareholders.

Leverage $(L)$ : Long-term debt divided by total assets of the company.

Size $(S)$ : Natural logarithm of total assets.

Growth $(G)$ : Percentage change in annual sales.

Other Outside Shareholders: Non-financial companies, non-governmental organizations (NGOs), trusts, charitable institutions, and association of persons.

Zimpex Private Limited- the largest shareholder of Kohinoor Textile Mills is incorporated in Lahore (refer to Figure 2). Its authorized capital is 5 million rupees and paid-up capital is 1 million rupees.

The relation between voting rights (VR), and Tobin's $q$ is illustrated in Figure 2 (for computing values of Tobin's $q$, we use panel average values of control variables in the estimating equation).

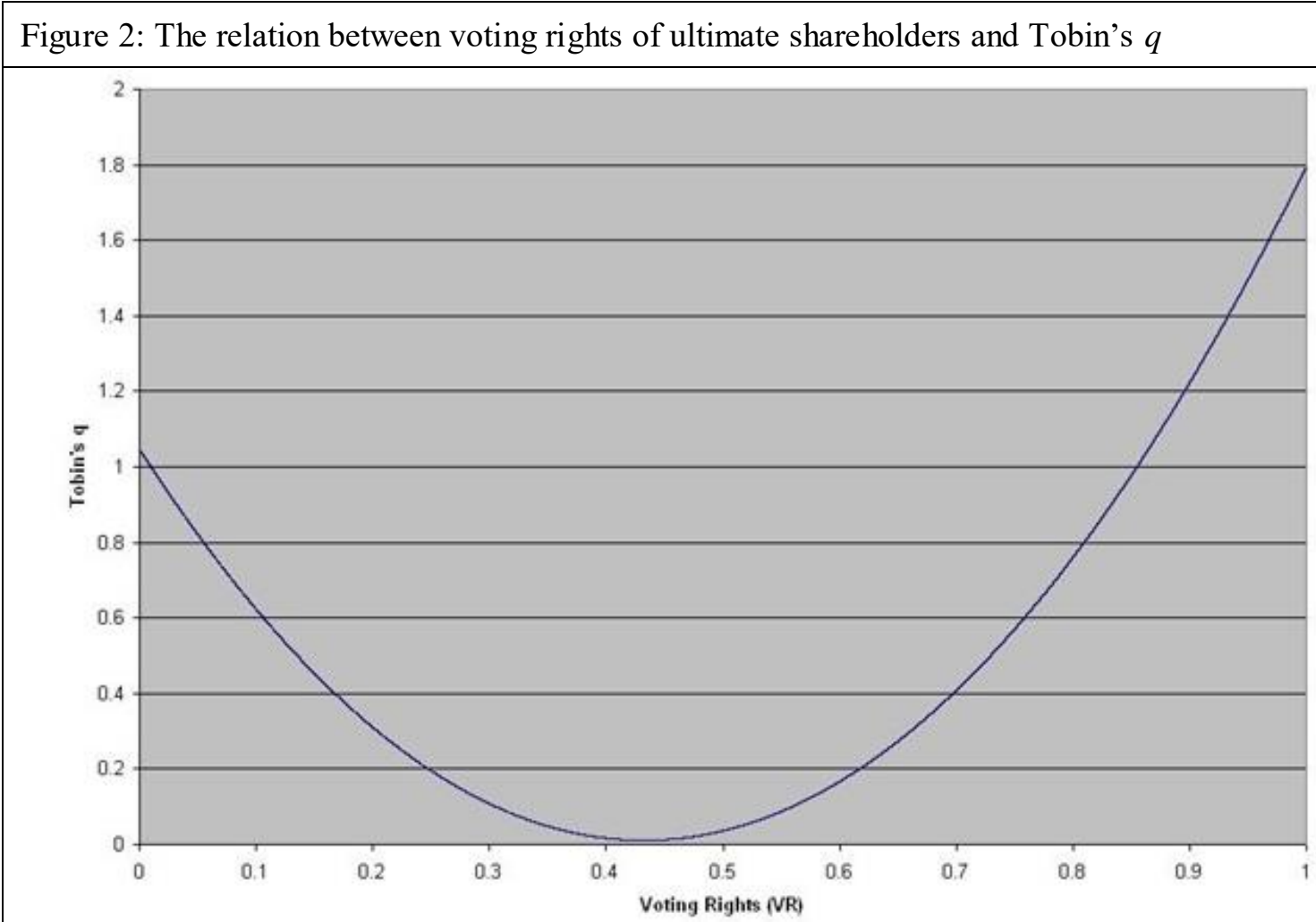

Source: Author 